\title{
PERAN RHIZOBAKTERI DALAM FITOEKSTRAKSI LOGAM BERAT KROMIUM PADA TANAMAN JAGUNG
}

\author{
Ali Pramono', MMA Retno Rosariastuti², Ngadiman³ dan Irfan D. Prijambada ${ }^{3}$ \\ (Diterima tanggal: 14 Juli 2011; Disetujui tanggal: 2 November 2011)
}

\begin{abstract}
Heavy metals are highly persistent in the environment and are known to alter soil ecosystem diversity, structure and function. Remediation of soil contaminated of heavy metals is important caused soil as medium for food production. Conventional methods for $\mathrm{Cr}(\mathrm{VI})$ remediation include physical and chemical. However, these methods were not widely explored due to high technology and costly. Due to this, the cost-effective, safe and friendly technology for in situ remediation is needed. The research was aimed to know the capability of rhizobacteria for phytoextraction of chromium on maize plant. The stages of this research include 1) tolerance test of rhizobacteria to $\mathrm{Cr}(\mathrm{VI}), 2)$ reduction test of rhizobacteria to $\mathrm{Cr}(\mathrm{VI})$, and 3) Absorption test of $\mathrm{Cr}(\mathrm{VI})$ on maize plant. The results of this research showed that Isolate 27 tolerated to $15 \mathrm{ppm}$ of $\mathrm{Cr}(\mathrm{VI})$. Isolate 27 reduced $15 \mathrm{ppm}$ of $\mathrm{Cr}(\mathrm{VI})$ within 18 hours completely. Isolate 27 helped the phytoextraction of chromium on maize plant up to 241 times. The continuous research is needed to know what type of organic acids that role in mechanism of phytoextraction on maize plant. Isolate 27 can be used as an inoculant in both phytoremediation protocols and in plant growth promotion.
\end{abstract}

Keywords: Cr(VI), maize plant, phytoextraction, rhizobacteria

\begin{abstract}
ABSTRAK
Logam berat bersifat persisten dalam lingkungan dan diketahui mengubah biodiversitas, struktur dan fungsi ekosistem tanah. Remediasi tanah terkontaminasi logam menjadi penting, karena tanah sebagai media penghasil bahan pangan. Pendekatan konvensional untuk remediasi tempat yang terkontaminasi logam meliputi fisika dan kimia, namun aplikasi proses-proses ini terbatas karena kendala teknologi dan ekonomi. Oleh karena itu diperlukan metode remediasi yang murah, aman dan ramah lingkungan seperti bioremediasi. Penelitian ini bertujuan untuk mengetahui kemampuan rhizobakteri dalam membantu fitoekstraksi logam berat kromium pada tanaman jagung. Tahapan penelitian meliputi 1) uji toleransi bakteri terhadap $\mathrm{Cr}(\mathrm{VI})$, 2) uji reduksi $\mathrm{Cr}(\mathrm{VI})$, dan 3) uji serapan $\mathrm{Cr}(\mathrm{VI})$ pada tanaman jagung. Hasil penelitian menunjukkan bahwa Isolat 27 toleran terhadap toksisitas $\mathrm{Cr}$ (VI) pada konsentrasi $15 \mathrm{ppm}$. Isolat 27 mereduksi Cr(VI) secara sempurna dalam waktu 18 jam. Isolat 27 membantu fitoekstraksi logam kromium pada tanaman jagung sebesar 241 kali dibandingkan kontrol. Perlu penelitian lebih lanjut untuk mengetahui jenis asam yang berperan dalam mekanisme fitoekstraksi pada tanaman jagung. Isolat 27 dapat digunakan sebagai inokulan dalam fitoremediasi dan pemacu pertumbuhan tanaman.
\end{abstract}

Kata Kunci: Cr(VI), fitoekstraksi, rhizobakteri, tanaman jagung

\section{PENDAHULUAN}

Logam berat bersifat persisten dalam lingkungan dan diketahui mengubah biodiversitas, struktur dan fungsi ekosistem tanah(1). Remediasi tanah terkontaminasi logam menjadi penting, karena tanah sebagai media penghasil bahan pangan. Remediasi tanah terkontaminasi logam meliputi fisika dan kimia, namun aplikasi proses-proses ini terbatas karena kendala teknologi dan ekonomi. Oleh karena itu diperlukan metode remediasi yang murah, aman dan ramah lingkungan yaitu bioremediasi (penggunaan

\footnotetext{
'Balai Penelitian Lingkungan Pertanian, Jakenan-Pati, Jl. Raya Jakenan-Jaken Km.5 Jakenan Pati, Telp/Fax. 0295 381592, email: ali_pramono@yahoo.com

${ }^{2}$ Universitas Sebelas Maret Surakarta

${ }^{3}$ Universitas Gadjah Mada Yogyakarta
} 
mikrobia atau sistem biologi lainnya untuk mendegradasi atau mentransformasi polutan di bawah kondisi terkendali), dan fitoremediasi (penggunaan tanaman untuk membersihkan polutan dari lingkungan tanah tercemar)(2).

Kromium adalah salah satu logam toksik yang secara luas digunakan untuk elektroplating, penyamakan kulit, pewarnaan tekstil, dan industri pemrosesan logam. Di alam, kromium dapat ditemukan sebagai $\mathrm{Cr}(\mathrm{VI})$ dan $\mathrm{Cr}(\mathrm{III})$. Kromium (III) mempunyai tingkat racun yang lebih rendah dan mudah diserap dalam tanah dan air, sedangkan chromium (VI) bersifat sangat toksik, tidak mudah diserap dalam tanah dan air dan garamnya bersifat larut(3).

Bakteri rhizosfer (rhizobakteri) memiliki mekanisme yang dapat menyebabkan perubahan ketersediaan unsur logam dalam tanah sehingga logam menjadi lebih mudah atau sukar diserap oleh tanaman. Secara alami tanaman memiliki sifat menyerap logam melalui mekanisme yang disebut fitoekstraksi. Logam diserap tanaman dari larutan tanah melalui akar tanaman dan penyerapannya dipengaruhi oleh ketersediaannya di dalam tanah. Sejumlah species tanaman mempunyai kemampuan hiperakumulasi logam berat, namun teknologi ini tidak cukup untuk meremediasi tempat dengan kontaminan yang beragam. Solusinya adalah kombinasi manfaat simbiosis mikrobia-tanaman dalam rhizosfer tanaman sehingga menjadi teknologi pembersihan yang efektif(4).

Rhizobakteri dapat dimanfaatkan untuk menangani lahan tercemar logam, khususnya kromium sehingga lahan tetap dapat dimanfaatkan untuk kegiatan pertanian yang aman bagi kesehatan manusia dan lingkungan. Beberapa rhizobakteri tersebut mampu meningkatkan serapan kromium di dalam jaringan tanamannya (fitoekstraksi), beberapa yang lain justru menurunkan serapan (fitostabilisasi). Penggalian potensi spesiesspesies rhizobakteri dari tempat tercemar kromium yang diduga berperan dalam fitoekstraksi merupakan hal yang menarik untuk diteliti. Tujuan penelitian ini adalah mengetahui kemampuan rhizobakteri dalam membantu fitoekstraksi logam berat kromium pada tanaman jagung.

\section{METODOLOGI}

Uji toleransi Isolat 27 terhadap $\mathrm{Cr}(\mathrm{VI})$

Penelitian ini dilakukan di Laboratorium Mikrobiologi Fakultas Pertanian UGM Yogyakarta pada tahun 2010. Pada penelitian sebelumnya telah didapatkan beberapa isolat bakteri asal tanah sawah tercemar logam kromium. Isolat 27 diuji toleransinya terhadap $\mathrm{Cr}(\mathrm{VI})$ dengan konsentrasi 6, 10, 15, $20,25,50,100,150,200,250,300,350,400$, 450, 500 dan 600 ppm pada medium Luria Bertani (LB) agar (komposisi: pepton $10 \mathrm{~g}$, ekstrak khamir 5 g, $\mathrm{NaCl} 5 \mathrm{~g}$ dan agar $15 \mathrm{~g}$ per liter akuades $)^{(5,6)}$

Uji Reduksi Cr(VI) oleh Isolat 27

Untuk mengetahui aktivitas reduksi Cr(VI), Isolat 27 diuji dengan perlakuan kultur bakteri (growing cells), sel (resting cells) dan supernatan secara terpisah yang diinteraksikan dengan $\mathrm{Cr}(\mathrm{VI})$

Reduksi Cr(VI) dengan growing cells

Isolat 27 pada kultur stok diambil dengan menggunakan ose dan diinokulasikan ke dalam $10 \mathrm{ml}$ medium LB cair. Kultur diinkubasi selama 10 jam pada suhu kamar dan dikocok 
dengan menggunakan shaker pada kecepatan $125 \mathrm{rpm}$, kemudian diambil 0,5 ml (OD600 =1) dan diinokulasikan ke dalam $20 \mathrm{ml}$ medium minimal (glukosa $10 \mathrm{~g}$; KH2PO4 6,8 g; K2HPO2 8,7 g; (NH4)2SO2 3,3 g; MgSO4 1,23 g per liter akuades)(7), diinkubasi pada suhu suhu kamar selama 20 jam dan dikocok pada kecepatan $125 \mathrm{rpm}$. Sebanyak 2,5 ml dari masing-masing kultur $($ OD600 $=1)$ diinokulasikan ke dalam $250 \mathrm{ml}$ medium minimal steril, diinkubasi selama 48 jam pada suhu kamar dan dikocok pada kecepatan 125 rpm. Pada jam ke-48 dihentikan kemudian ditambahkan $\mathrm{Cr}(\mathrm{VI})$ dalam bentuk $\mathrm{K} 2 \mathrm{Cr} 2 \mathrm{O} 7$ dengan konsentrasi 15 ppm. Kemudian diinkubasi selama 24 jam dengan kondisi yang sama. Pengambilan sampel dilakukan untuk mengetahui pertumbuhan bakteri dan kadar sisa Cr(VI) pada setiap interval enam jam. Pertumbuhan bakteri diukur kerapatan optiknya dengan menggunakan spektrofotometer pada panjang gelombang 600 nm. Perubahan kadar Cr(VI) dalam medium selama pertumbuhan bakteri diukur dengan metode difenil karbazid (DPC) menurut Thacker \& Madamdawar (2005)(8).

\section{Reduksi Cr(VI) dengan resting cells}

Isolat 27 ditumbuhkan secara bertingkat dengan menginokulasikan ke dalam 250 $\mathrm{ml}$ medium minimal steril, diinkubasi pada suhu kamar selama 48 jam dan dikocok pada kecepatan $125 \mathrm{rpm}$. Setelah diinkubasi 48 jam, sel dipanen melalui sentrifugasi (10.000 rpm selama lima menit PADA SUHU $4^{\text {OC). }}$ Supernatan yang diperoleh digunakan untuk perlakuan berikutnya. Sel kemudian dicuci dua kali dalam $10 \mathrm{mM}$ buffer Tris $\mathrm{HCl}(\mathrm{pH}$ $7,2)$ dan diresuspensi dalam buffer Tris $\mathrm{HCl}$
$250 \mathrm{ml}(6)$. Suspensi sel dan supernatan secara terpisah dimasukkan masing-MASING KE DALAM tabung Erlenmeyer steril dan ditambahkan $\mathrm{Cr}(\mathrm{VI})$ dalam bentuk $\mathrm{K} 2 \mathrm{Cr} 2 \mathrm{O} 7$ dengan konsentrasi yang sama pada perlakuan growing cells. Sebagai kontrol adalah buffer Tris $\mathrm{HCl}$ tanpa suspensi bakteri. Perlakuan dan kontrol kemudian diinkubasikan dengan pengocokan pada suhu kamar dengan kecepatan 125 rpm selama 24 jam. Pada interval enam jam diambil sampel untuk ditentukan kadar $\mathrm{Cr}(\mathrm{VI})$.

\section{Reduksi Cr(VI) dengan supernatan}

Supernatan yang diperoleh dari perlakuan sebelumnya dimasukkan dalam Erlenmeyer steril, kemudian ke dalamnya ditambahkan $\mathrm{Cr}(\mathrm{VI})$ dalam bentuk $\mathrm{K} 2 \mathrm{Cr} 2 \mathrm{O} 7$ dengan konsentrasi yang sama pada perlakuan growing cells dan diinkubasi dengan pengocokan pada suhu kamar dengan kecepatan 125 rpm selama 24 jam. Pada interval enam jam diambil sampel untuk ditentukan kadar Cr(VI).

\section{Penentuan kadar Cr(VI)}

Satu ml medium cair yang mengandung kromium dimasukkan ke dalam tabung ependorf dan disentrifugasi $10.000 \mathrm{rpm}$ selama lima menit. Sebanyak $200 \mu 1$ atau 400 $\mu 1$ sampel atau standard $\mathrm{K} 2 \mathrm{Cr} 2 \mathrm{O} 7$ diambil dan volume dibuat satu $\mathrm{ml}$ dengan penambahan akuades. Dalam larutan tersebut ditambahkan $330 \mu 16$ M H2SO4 dan $400 \mu 1$ DPC $(0,25 \%$ $\mathrm{w} / \mathrm{v})$. DPC $0,25 \%(\mathrm{w} / \mathrm{v})$ disiapkan dengan melarutkan 0,25 g difenil karbazid ke dalam $100 \mathrm{ml}$ aseton. Volume akhir dibuat $10 \mathrm{ml}$ dengan penambahan akuades, dan campuran dibiarkan bereaksi selama 10 menit, kemudian diukur dengan spektrofotometer UV-VIS pada panjang gelombang $540 \mathrm{~nm}(8)$. 


\section{Uji Serapan Cr oleh Tanaman}

Penelitian ini merupakan percobaan di rumah kaca untuk mengetahui pengaruh hasil interaksi Isolat 27 terhadap $\mathrm{Cr}(\mathrm{VI})$ dan serapan Croleh tanaman. Jenis tanaman yang digunakan adalah jagung (Zea mays). Media tanam berupa tanah pasir steril sebanyak 5 $\mathrm{kg}$ berat kering mutlak/pot. Media tanam dimasukkan dalam pot, kemudian diberi pupuk dasar NPK sebanyak satu tablet per pot. Benih jagung ditanam dan dipelihara hingga tumbuh baik sekitar satu minggu, kemudian diberi perlakuan pemberian cairan hasil interaksi Isolat 27 dengan kromium (perlakuan growing cells, resting cells dan supernatan). Masingmasing perlakuan terdiri dari tiga ulangan. Tanaman dipelihara selama satu bulan untuk dipanen biomasanya, dipisahkan antara akar dan trubusnya. Parameter yang diukur adalah berat kering brangkasan, kadar Cr total dalam akar dan trubus tanaman. Pengukuran Cr total dilakukan dengan menggunakan AAS (atomic absorption spectrophotometry).

Metode preparasi dan ekstraksi sampel akar dan trubus untuk penentuan kadar Cr total(9). Sampel tanaman tersebut dikeringkan dan dioven pada suhu 90oC selama 48 jam. Sampel tanaman kering diblender dan diayak dengan saringan dua mm. Sampel akar dan trubus diekstraksi menggunakan metode digesti asam nitrat/perklorat. Sebanyak $0,5 \mathrm{~g}$ sampel kering oven dimasukkan Erlenmeyer $125 \mathrm{ml}$, ditambahkan empat ml 1:1 HNO3/ $\mathrm{HClO} 4$, dan dibiarkan semalam. Sampel ditempatkan di atas kompor dan dipanaskan sampai asap putih mulai hilang dan cairan tampak jernih. Cairan tersebut kemudian diencerkan dengan akuades hingga $10 \mathrm{ml}$ dan disaring dengan kertas Whatman. Filtrat siap diukur kadar Cr totalnya dengan AAS.

\section{HASIL DAN PEMBAHASAN}

Pada penelitian sebelumnya, telah diisolasi bakteri-bakteri rhizosfer (rhizobakteri) sebanyak 39 macam isolat dari tanah sawah tercemar limbah industri di Desa Sambirembe Kec. Kalasan Kab. Sleman Yogyakarta. Seleksi terhadap isolat rhizobakteri untuk mengetahui kemampuan fitoekstraksi logam kromium pada tanaman jagung juga telah dilakukan. Isolat 27 mempunyai kemampuan meningkatkan fitoekstraksi(10). Isolat 27 selanjutnya juga telah diidentifikasi, yaitu Agrobacterium tumefaciens. Isolat 27 mempunyai potensi untuk dikembangkan sebagai rhizobakteri yang mampu meningkatkan fitoekstraksi logam kromium, namun mekanisme tersebut belum diketahui. Rhizobakteri memiliki suatu mekanisme yang menyebabkan terjadinya perubahan mobilitas unsur logam, sehingga menjadi lebih mudah diserap tanaman atau sebaliknya.

\section{Uji toleransi rhizobakteri terhadap $\mathrm{Cr}$ (VI)} Isolat 27 diuji toleransinya terhadap $\mathrm{Cr}(\mathrm{VI})$. Kemampuan tumbuh pada medium LB agar yang diberi kromium dapat dilihat pada Tabel 1. Isolat 27 mempunyai konsentrasi penghambatan minimum (Minimum Inhibiton Concentration / MIC) sebesar $300 \mathrm{mg}$ $\mathrm{Cr}(\mathrm{VI}) / 1$. Pada kondisi in vitro, toleransi terhadap $\mathrm{Cr}$ tergantung pada tipe medium yang digunakan. MIC yang dicapai pada medium kaya nutrisi lebih tinggi 2-5 kali daripada dengan menggunakan medium minimal karena logam berat dapat terikat 
Tabel 1 Hasil pertumbuhan bakteri Isolat 27 pada medium LB agar yang diberi Cr(VI)

\begin{tabular}{|c|c|c|c|c|c|c|c|c|c|c|c|c|c|c|c|c|}
\hline \multirow{2}{*}{ Isolat } & \multicolumn{16}{|c|}{ Konsentrasi Kromium (VI) (ppm) } \\
\hline & 6 & 10 & 15 & 20 & 25 & 50 & 100 & 150 & 200 & 250 & 300 & 350 & 400 & 450 & 500 & 600 \\
\hline 27 & + & + & + & + & + & + & + & + & + & + & + & - & - & - & - & - \\
\hline
\end{tabular}

Keterangan : tanda (+) menunjukkan ada pertumbuhan dan (-) tidak ada pertumbuhan

oleh komponen medium khususnya senyawa organik dan fosfat(11).

Untuk mengurangi kemungkinan kompleksasi $\mathrm{Cr}(\mathrm{VI})$ dengan komponen medium dan memungkinkan pengujian toksisitas $\mathrm{Cr}(\mathrm{VI})$ terhadap bakteri lebih akurat maka dalam penelitian ini digunakan medium minimal yang disuplementasi dengan glukosa pada kadar rendah $(1 \%)$. Hasil pengujian toleransi Isolat 27 terhadap Cr(VI) disajikan pada Gambar 1. Kadar Cr(VI) 6, 10 dan 15 ppm diujikan pada isolat tersebut. Kadar Cr(VI) yang lebih tinggi dari 15 ppm dalam medium pertumbuhan ini menyebabkan isolat tersebut tidak mampu tumbuh. Pemberian Cr(VI) sebesar 6 ppm atau lebih pada awal pertumbuhan mengakibatkan isolat bakteri tidak mampu tumbuh. Untuk itu,
Isolat 27 ditumbuhkan terlebih dahulu selama 48 jam agar mencapai akhir fase logaritma, kemudian baru diberikan $\mathrm{Cr}$ (VI) untuk melihat pengaruhnya terhadap pertumbuhan sel (Gambar 1). Medium tanpa kromium (kontrol) menunjukkan tidak terjadi perubahan warna kekuningan, medium kultur yang diberi kromium berwarna kekuningan yang intensitasnya makin kuat dengan besarnya kadar kromium.

Meskipun tidak dilakukan pengukuran kadar $\mathrm{Cr}(\mathrm{VI})$, terjadinya perubahan warna kultur dan kenaikan jumlah sel setelah diinkubasi tiga hari menandakan bahwa $\mathrm{Cr}(\mathrm{VI})$ telah berkurang/direduksi. Reduksi Cr(VI) menjadi Cr(III) yang kurang toksik merupakan mekanisme dasar resistensi terhadap kromat pada bakteri(12).

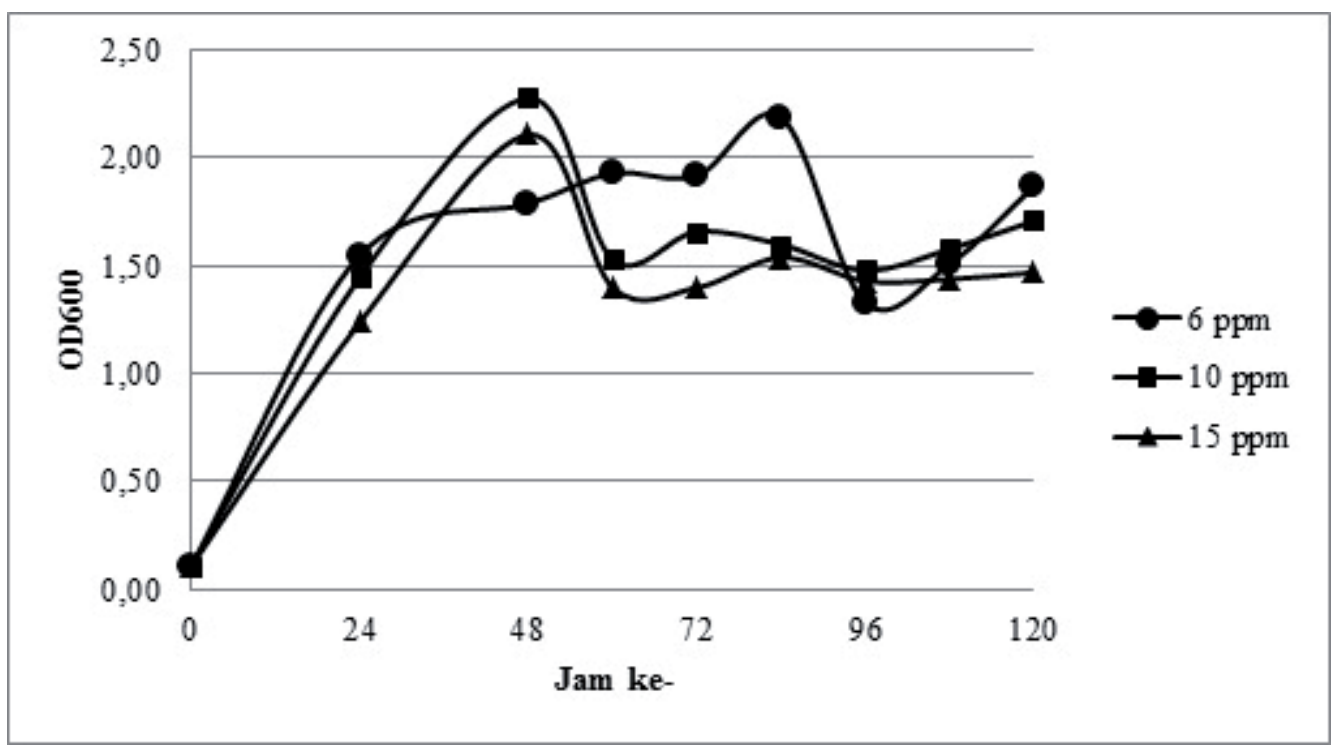

Gambar 1 Pertumbuhan Isolat 27 pada medium minimal dengan berbagai konsentrasi $\mathrm{Cr}(\mathrm{VI})$ 


\section{Uji Reduksi Cr(VI) oleh Isolat 27}

\section{Reduksi Cr(VI) dengan growing cells}

Pertumbuhan sel Isolat 27 terhambat dengan keberadaan $\mathrm{Cr}(\mathrm{VI})$ di dalam medium minimal dan reduksi $\mathrm{Cr}(\mathrm{VI})$ berkaitan dengan pertumbuhan sel (Gambar 2). Isolat 27 ditumbuhkan terlebih dahulu agar mencapai akhir fase eksponensial (kira-kira 48 jam) dan kemudian diberi $\mathrm{Cr}(\mathrm{VI})$. Isolat tersebut aktif mereduksi Cr(VI) menjadi Cr(III) ketika ditumbuhkan pada kondisi aerobik. Isolat tersebut dapat mentoleransi toksisitas dan tumbuh pada kadar 15 ppm Cr(VI), dan analisis terhadap jumlah $\mathrm{Cr}(\mathrm{VI})$ yang tersisa dalam fraksi supernatan menunjukkan bahwa jumlah $\mathrm{Cr}(\mathrm{VI})$ telah berkurang karena direduksi (Tabel 2). Hal ini karena bakteri tersebut telah beradaptasi di lingkungan tercemar logam kromium sehingga mampu berkembang biak pada aras toksik.

Penghambatan pertumbuhan sel terjadi karena senyawa $\mathrm{Cr}(\mathrm{VI})$ dapat menginduksi mutasi frame-shift, substitusi pasangan basa pada G-C dan A-T pada sel bakteri. Diduga bahwa fungsi SOS bakteri dapat memperbaiki kerusakan DNA yang disebabkan oleh Cr(VI)(13, 14). Penurunan jumlah sel dan peningkatan periode lag oleh karena penambahan $\mathrm{Cr}(\mathrm{VI})$ disebabkan meningkatnya waktu adaptasi untuk perbaikan DNA selama pemaparan $\mathrm{Cr}(\mathrm{VI})$ di dalam medium. Namun pada akhir inkubasi, pertumbuhan sel kembali meningkat. Isolat 27 mampu mereduksi Cr(VI) setelah ditumbuhkan hingga mencapai fase akhir logaritma, baik dengan induksi Cr(VI) pada awal pertumbuhan maupun tanpa induksi. Isolat 27 mereduksi $\mathrm{Cr}(\mathrm{VI})$ hingga jam ke-12 setelah pemaparan $\mathrm{Cr}(\mathrm{VI})$ dan menunjukkan kemampuan mereduksi Cr(VI) secara sempurna setelah 18 jam. Proses reduksi membutuhkan ketersediaan energi yang cukup, baik dalam bentuk senyawa organik maupun anorganik. Sel mereduksi kromat baik dengan maupun tanpa diinduksi kromat terlebih dahulu(15).

Konsentrasi kromat yang lebih tinggi mencegah multiplikasi bakteri tetapi tidak mencegah bakteri untuk mereduksi kromat. Resistensi kromat pada Isolat 27 tidak terkait dengan kemampuan reduksi kromat yang menunjukkan bahwa penentuan resistensi kromat terletak pada plasmid, sedangkan reduksi kromat terletak dalam kromosom pada Pseudomonas fluorescens. Reduksi pada Pseudomonas fluorescens dan Bacillus sp ini terjadi secara enzimatik, karena dikatalis oleh ekstrak sel ${ }^{(15)}$.

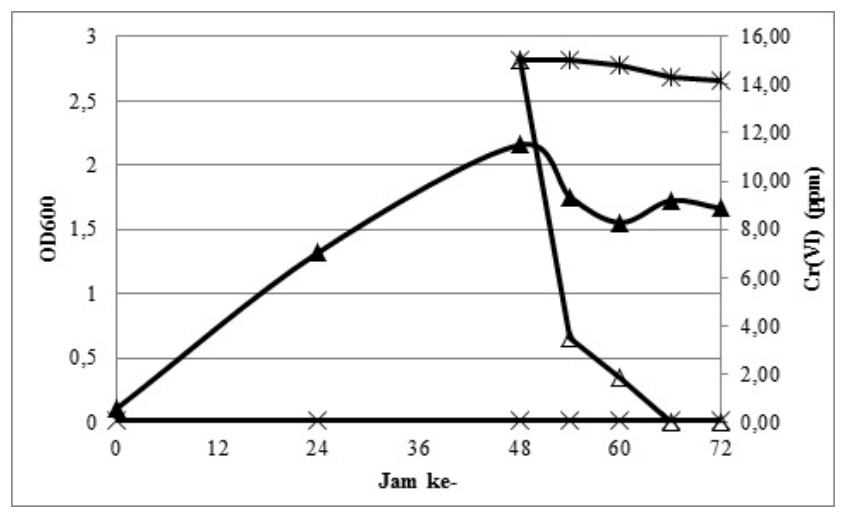

Gambar 2 Pertumbuhan Isolat 27 dan reduksi $\mathrm{Cr}(\mathrm{VI})$ pada kondisi growing. $\mathrm{OD}_{600}$ Isolat $27(\mathbf{l}$ - ), kontrol ( $\bullet$ ); kadar $\mathrm{Cr}(\mathrm{VI})$ Isolat $27(\boldsymbol{-})$ ), dan kontrol ( 
Tabel 2 Kadar Cr(VI) jam ke-48 hingga ke-72 pada perlakuan growing cell Isolat 27

\begin{tabular}{cccccc}
\hline & \multicolumn{5}{c}{ Kadar Cr(VI) (ppm) } \\
Jam ke- \\
\cline { 2 - 6 } Perlakuan & 48 & 54 & 60 & 66 & 72 \\
\hline Isolat 27 & 15.0 & 3.5 & 1.8 & 0.0 & 0.0 \\
Kontrol & 15.0 & 15.0 & 14.83 & 14.33 & 14.17 \\
\hline
\end{tabular}

Data rata-rata dari 3 ulangan

\section{Reduksi Cr(VI) dengan resting cells}

Isolat 27 ditumbuhkan dalam medium minimal, setelah mencapai fase akhir eksponensial, sel dipanen lalu dicuci dua kali dengan buffer Tris HCl. Dengan buffer yang sama, sel disuspensikan kemudian dipapar $\mathrm{Cr}(\mathrm{VI})$ dengan kadar 15 ppm. Pada Tabel 3 terlihat penurunan secara drastis kadar Cr(VI) pada enam jam pertama inkubasi, meskipun hingga akhir inkubasi $\mathrm{Cr}(\mathrm{VI})$ yang tereduksi hampir $50 \%$.

Penurunan kadar Cr(VI) pada perlakuan tersebut kemungkinan dapat disebabkan oleh tiga hal, yaitu biosorpsi oleh dinding sel bakteri, aktivitas enzim kromat reduktase di dalam sel, dan metabolit berupa asam-asam organik. Biosorpsi, yaitu proses pengambilan logam oleh sel mikroorganisme secara pasif (tidak membutuhkan energi). Pengikatan ion logam secara biosorpsi pada organisme menggunakan kapsul, polimer, ekstraseluler dan gugus fungsional yang terdapat pada dinding sel mikroorganisme. Organisme yang dapat melakukan biosorpsi adalah bakteri, kapang, khamir, dan algae. Agen pengkhelat siderofor yang dimiliki oleh Enterobacter memiliki gugus reaktif yaitu asam dikarboksilat, asam polihidroksi, dan asam fenolik. Gugus reaktif berfungsi untuk mengikat kromium, uranium yang terdapat di lingkungan $^{(16,17,18) \text {. }}$

Bakteri dapat mereduksi kromat di bawah kondisi aerobik dan anaerobik dimana enzim yang berperan adalah chromate reductase secara konstitutif. Reduksi kromat menjadi Cr(III) secara cepat dilakukan oleh enzim chromate reductase yang diisolasi dari P. putida MK1, P. putida PRS2000, Pseudomonas ambigua, Arthrobacter spp., dan Bacillus spp. Beberapa enzim reduktase memerlukan NADH atau NADPH untuk aktivitas maksimum, termasuk pseudomonad tanah. Reductase berasal dari sitoplasma, lisis sel atau sekresi dan mereduksi Cr(VI) secara ekstraseluler, menghasilkan deposit Cr pada permukaan sel dan terikat oleh EPS (extracellular polymeric substances) dalam $\operatorname{larutan}^{(19)}$.

Tabel 3 Kadar Cr(VI) jam ke-48 hingga ke-72 pada perlakuan resting cell Isolat 27

\begin{tabular}{cccccc}
\hline \multirow{2}{*}{ Perlakuan } & \multicolumn{5}{c}{ Kadar Cr(VI) (ppm) } \\
& & \multicolumn{5}{c}{ Jam ke- } \\
\cline { 2 - 6 } & 48 & 54 & 60 & 66 & 72 \\
\hline Isolat 27 & 15.0 & 8.8 & 7.9 & 7.6 & 7.6 \\
Data rata-rata dari 3 ulangan & 15.0 & 14.8 & 14.4 & 14.30 & 14.1 \\
\cline { 2 - 6 } & Kontrol & \multicolumn{5}{c}{}
\end{tabular}




\section{Reduksi Cr(VI) dengan supernatan}

Supernatan yang diperoleh dari pemisahan sel bakteri dipapar $\mathrm{Cr}(\mathrm{VI})$ dengan kadar 15 ppm, kemudian diinkubasi dengan pengocokan selama 24 jam. Penurunan kadar Cr(VI) secara drastic sebenarnya terjadi sesaat setelah $\mathrm{Cr}(\mathrm{VI})$ dengan supernatan. Penurunan kadar $\mathrm{Cr}(\mathrm{VI})$ terbesar yaitu dari 15 ppm menjadi 2,2 ppm pada 6 jam pertama inkubasi (Tabel 4).

Untuk mengklarifikasi mekanisme penurunan $\mathrm{Cr}(\mathrm{VI})$ melalui reduksi, diuji apakah sel mampu menurunkan kadar $\mathrm{Cr}(\mathrm{VI})$. Tabel 5 menunjukkan kemampuan reduksi kromat oleh Isolat 27 dalam kondisi growing. Aktivitas penurunan $\mathrm{Cr}(\mathrm{VI})$ nampaknya berasal dari fraksi terlarut dalam supernatan. Supernatan diperoleh dari cairan kultur yang disentrifugasi $\mathrm{Cr}(\mathrm{VI})$ dan diduga terdapat metabolit (asam organik atau enzim) yang dilepaskan oleh sel ke dalam medium kultur. Hal ini terjadi melalui sekresi atau lisis sel. Reduksi Cr(VI) oleh enzim chromate reductase terjadi karena asam-asam organik bertindak sebagai sumber donor elektronnya. Bakteri pereduksi Cr(VI) dapat menggunakan bermacam-macam senyawa organik sebagai donor elektron dalam proses reduksi $\mathrm{Cr}(\mathrm{VI})$. Donor elektron dapat berupa karbohidrat dengan berat molekul rendah, asam-asam amino, dan asam-asam lemak. Glukosa digunakan sebagai donor elektron pada sebagian besar bakteri pereduksi $\mathrm{Cr}(\mathrm{VI})(14), 21)$ dan trypton diketahui efektif sebagai donor elektron pada Enterobacter cloaca $^{(21)}$.

Reduksi melalui perlakuan resting cell pada penelitian ini lebih kecil dibandingkan growing cell maupun supernatan. Reduksi Cr(VI) yang toksik menjadi $\mathrm{Cr}$ (III) yang kurang toksik adalah proses yang mengkonsumsi elektron. Sel menunjukkan aktivitas reduksi Cr(VI) ketika ada atau tidaknya donor elektron yang ditambahkan.

Tabel 4 Kadar Cr(VI) jam ke-48 hingga ke-72 pada perlakuan supernatan Isolat 27

\begin{tabular}{cccccc}
\hline \multirow{2}{*}{ Perlakuan } & \multicolumn{5}{c}{ Kadar Cr(VI) (ppm) } \\
& 48 & 54 & 60 & 66 & 72 \\
\cline { 2 - 6 } & 48.0 & 2.2 & 2.0 & 0.0 & 0.0 \\
\hline Isolat 27 & $15.0-$ \\
Kontrol & 15.0 & 15.0 & 14.8 & 14.60 & 14.2 \\
\hline
\end{tabular}

Data rata-rata dari 3 ulangan

Tabel 5 Kemampuan reduksi beberapa isolat bakteri terhadap $\mathrm{Cr}(\mathrm{VI}) 15 \mathrm{ppm}$ pada perlakuan growing, resting cell dan supernatan

\begin{tabular}{crrr}
\hline \multirow{2}{*}{ Perlakuan } & \multicolumn{3}{c}{$\% \mathrm{Cr}(\mathrm{VI})$ reduction } \\
\cline { 2 - 4 } & Growing & Resting & Supernatan \\
\hline Isolat 27 & 87.78 & 34.89 & 86.67 \\
Kontrol & 2,00 & 1,78 & - \\
\hline
\end{tabular}

Data rata-rata dari 3 ulangan 
Pada penelitian ini diduga bahwa reduksi Cr(VI) terkait membran sel dalam resting cell dan glukosa merupakan donor elektron pada proses reduksi $\mathrm{Cr}(\mathrm{VI})$ dalam growing cell. Berdasarkan pengukuran $\mathrm{pH}$, Isolat 27 mereduksi $\mathrm{Cr}(\mathrm{VI})$ dengan mekanisme penghasilan asam. Perlakuan growing cell dan supernatan menyebabkan penurunan $\mathrm{pH}$ selama inkubasi dan perlakuan hingga 4,6. Reduksi Cr(VI) dapat terjadi melalui reaksi kimia yang berkaitan dengan senyawa seperti asam-asam amino, nukleotida, gula, vitamin, asam organik atau glutathione. Reduksi $\mathrm{Cr}(\mathrm{VI})$ secara enzimatik berkaitan membran sel atau fraksi terlarut, dan dapat terjadi pada kondisi aerobik atau anaerobik(22). Lebih dari 50\% enzim chromate reductase aktif pada pH antara 5,5 hingga 7,5. pH optimum enzim chromate reductase berkaitan erat dengan $\mathrm{pH}$ pertumbuhan optimum mikroorganisme yang mendekati netral ${ }^{(23)}$.

\section{Uji Serapan Spesies Cr oleh Tanaman}

Kromium masuk ke dalam tanaman tidak melalui jalur mekanisme spesifik. Jalur logam $\mathrm{Cr}(\mathrm{VI})$ dapat masuk melalui beberapa mekanisme unsur-unsur penting, seperti sulfat(33). Masuknya Cr(VI) dalam jalur sulfat dimungkinkan karena stuktur kromium yang mirip dengan SO42- membuat $\mathrm{Cr}$ (VI) mudah diserap melalui mekanisme sistem transpor sulfat. Selain sulfat, $\mathrm{Cr}(\mathrm{VI})$ juga dapat bergabung dengan mekanisme sistem unsur besi (Fe), belerang (S), dan fosfor $(\mathrm{P})$ (24). Sementara untuk Cr(III), pengambilan oleh tanaman terjadi secara pasif melalui pertukaran kation pada dinding sel. Hal ini menyebabkan konsentrasi Cr(VI) lebih tinggi terserap dalam tanaman daripada $\mathrm{Cr}(\mathrm{III})$.
Toksisitas logam berat terhadap terhadap tanaman bervariasi tergantung jenis logam dan konsentrasinya. Gejala visual toksisitas Cr pada tanaman jagung dalam penelitian ini adalah pertumbuhan yang kerdil, sistem perakaran yang kurang berkembang, daun sempit, mengggulung dan tidak berwarna (klorosis), serta reduksi biomasa. Pelayuan dan kematian tanaman yang cepat juga dilaporkan sebagai hasil pemaparan kadar $\mathrm{Cr}$ yang tinggi(25). Melalui mekanisme reduksi Cr(VI) menjadi Cr(III) oleh rhizobakteri dan kemudian terjadi khelating $\mathrm{Cr}$ (III) dengan asam-asam organik membentuk kompleks maka kromium meningkat kelarutan dan mobilitasnya sehingga dapat terserap tanaman.

Pada penelitian ini, setelah perlakuan growing, resting dan supernatan diinteraksikan dengan Cr(VI) sebesar enam ppm kemudian diujikan pada tanaman jagung. Tanaman dipelihara selama satu bulan, diamati pertumbuhannya dan setelah panen diukur kadar $\mathrm{Cr}$ total dalam akar dan trubusnya. Hasil pengamatan pertumbuhan menunjukkan bahwa perlakuan Isolat 27 menyebabkan pertumbuhan lebih baik (Gambar 3) dan meningkatkan berat kering tanaman (Tabel 6). Berat kering tanaman pada perlakuan pemberian cairan kultur Isolat 27 sebesar 4,7 gram, meningkat hampir tujuh kali lipat dibandingkan kontrol. Kemampuan membantu fitoekstraksi dinyatakan oleh perkalian antara serapan $\mathrm{Cr}$ tanaman, berat kering tanaman dan serapan $\mathrm{Cr}$ oleh akar dibanding serapan $\mathrm{Cr}$ trubus. Tabel 6 menunjukkan kemampuan Isolat 27 dalam membantu fitoekstraksi pada tanaman jagung dengan perlakuan growing, resting dan supernatan. Pada perlakuan growing cell, Isolat 27 membantu fitoekstraksi tanaman 

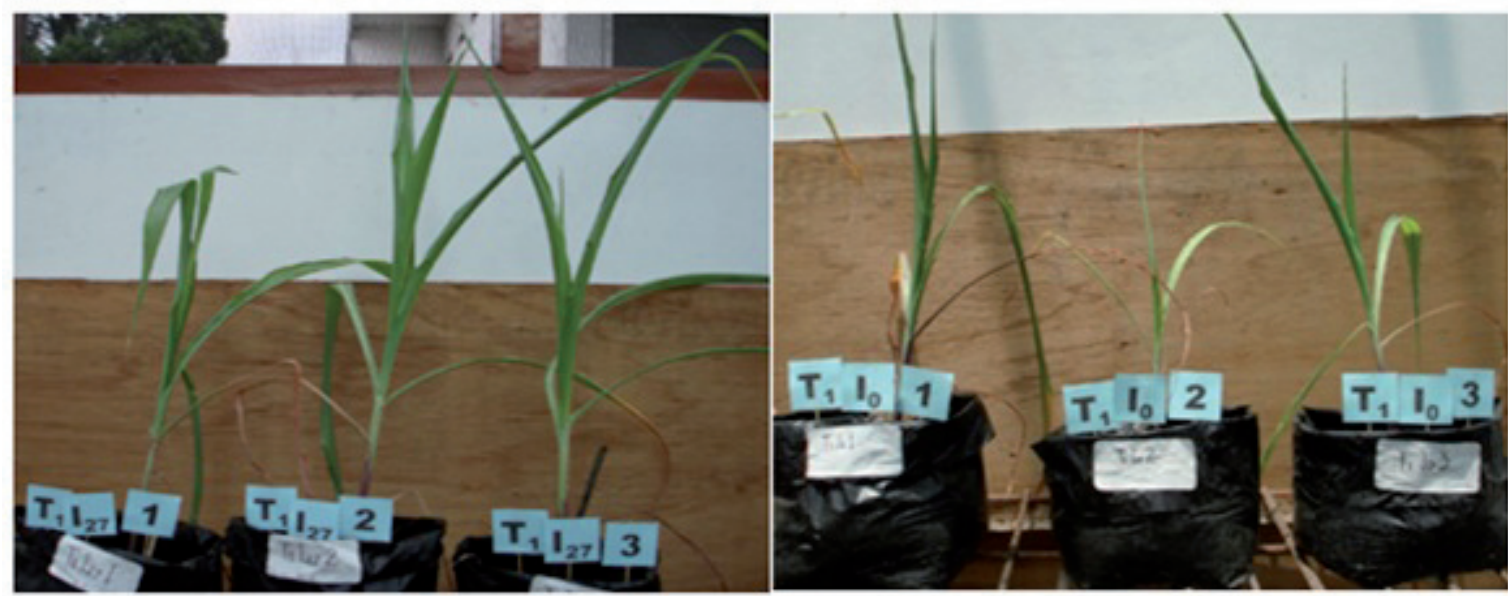

Gambar 2 Pertumbuhan tanaman jagung pada perlakuan pemberian kultur Isolat 27 (kiri) dan kontrol (kanan)

jagung sebesar 241 kali dibandingkan kontrol.

Diduga bahwa ada keterkaitan antara asam yang dihasilkan isolat bakteri dengan hasil reduksi $\mathrm{Cr}$ (III) sehingga mudah terserap ke dalam jaringan tanaman.

Selain dapat mereduksi ion kromium, rhizobakteri juga dapat mendukung pertumbuhan tanaman dengan mensintesis prekursor fitohormon, vitamin, enzim, siderofor, dan antibiotik(4). Bakteri rhizosfer, misalnya Pseudomonas spp., Azospirillum spp., dan Agrobacterium spp., meningkatkan pertumbuhan tanaman dan penyerapan nutrien pada tanaman jagung, gandum dan legum(26). Asam-asam organik merupakan khelator dan berperan penting dalam akumulasi dan detoksifikasi logam dalam tanaman. Sekitar $28 \%$ Ni ditranslokasikan oleh sitrat di dalam daun $\mathrm{T}$. goesingense terutama dalam vakuola(27). Ada korelasi positif antara konsentrasi $\mathrm{Zn}$ terlarut di dalam trubus $\mathrm{T}$. careulescens dan konsentrasi asam malat dan oksalat(28). Oksalat adalah asam dikarboksilat kuat dan bertindak sebagai khelator logam. Oksalat dapat berintegrasi dengan kadar $\mathrm{Cr}$ di dalam daun dan mungkin berhubungan dengan resistensi Cr pada rumput L. hexandra(29). Asam-asam organik (sitrat dan oksalat) telah dilaporkan berperan penting dalam fitoremediasi pada tanah terkontaminasi $\mathrm{Cr}$

Tabel 6 Kemampuan Isolat 27 dalam membantu fitoekstraksi logam kromium pada tanaman jagung dengan perlakuan growing, resting dan supernatant

\begin{tabular}{|c|c|c|c|c|c|c|}
\hline Perl & $\begin{array}{c}\text { Serapan } \\
\text { Cr Tan } \\
\text { A }\end{array}$ & $\begin{array}{c}\text { BK Tan } \\
\text { B } \\
\end{array}$ & $\begin{array}{c}\text { Serapan Cr } \\
\text { Akar } \\
\text { C } \\
\end{array}$ & $\begin{array}{c}\text { Serapan Cr } \\
\text { Trubus } \\
\text { D } \\
\end{array}$ & $\begin{array}{c}(\mathrm{A} \times \mathrm{B} \times \mathrm{C}) / \\
\mathrm{D}\end{array}$ & $\mathrm{Perl} / \mathrm{K}$ \\
\hline G-I0 & 19.104 & 0.700 & 7.242 & 11.862 & 8.165 & 1.000 \\
\hline G-I27 & 45.091 & 4.700 & 40.717 & 4.374 & 1972.999 & 241.641 \\
\hline R-I0 & 216.102 & 1.933 & 203.271 & 12.831 & 6618.757 & 1.000 \\
\hline R-I27 & 573.787 & 4.567 & 563.552 & 10.235 & 144271.961 & 21.798 \\
\hline S-I27 & 8.256 & 1.167 & 7.515 & 0.741 & 97.669 & 11.962 \\
\hline
\end{tabular}

$\mathrm{G}=$ Growing cell, $\mathrm{R}=$ Resting Cell dan $\mathrm{S}=$ Supernatan Data rata-rata dari 3 ulangan 
dengan meningkatkan pengambilan $\mathrm{Cr}$ dan translokasi Cr dalam akar. Selain itu, senyawa pengkhelat ini juga dapat meningkatkan ketahanan tanaman terhadap tingkat racun $\operatorname{logam}(30,31)$. Asam-asam organik ini juga dapat mengasamkan tanah dan menciptakan $\mathrm{Cr}(\mathrm{VI})$ lebih banyak sehingga dapat dengan cepat terserap oleh tanaman(32).

\section{KESIMPULAN}

Dari hasil penelitian ini disimpulkan, Isolat 27 toleran terhadap toksisitas $\mathrm{Cr}(\mathrm{VI})$ pada konsentrasi 15 ppm.

Isolat 27 mereduksi $\mathrm{Cr}(\mathrm{VI})$ secara sempurna dalam waktu 18 jam.

Isolat 27 membantu fitoekstraksi logam kromium pada tanaman jagung sebesar 241 kali dibandingkan kontrol.

Perlu penelitian lebih lanjut untuk mengetahui jenis asam yang berperan dalam mekanisme fitoekstraksi pada tanaman jagung.

Isolat 27 dapat digunakan sebagai inokulan dalam fitoremediasi dan pemacu pertumbuhan tanaman.

\section{DAFTAR PUSTAKA}

1. Baath E. 1989. Effects of Heavy Metals in Soil on Microbial Processes and Population, Water Air Soil Pollut. Vol. 47, pp. 335-379.

2. Muller JG, Cerniglia CE, and Pritchard PH, 1996. Bioremediation of environments contaminated by polycyclic aromatic hydrocarbons. In: Ronald LC, Crawford DL (eds) Bioremediation: principles and applications. Cambridge University Press, Cambridge, pp 125-194

3. Kotas J and Stasicka Z. 2000 Chromium occurrence in the environment and methods of its speciation. Environ Pollut 107:263-283.

4. Khan MS, AZaidi, PA Wani and MOves. 2009. Role of plant growth promoting rhizobacteria in the remediation of metal contaminated soils. Environ Chem Lett 7:1-19.

5. Kannan SK, KJ Lee, Krishnamoorthy, A Purusothaman, K Shanthi and NR Rao. 2007. Aerobic Chromate Reducing Bacillus cereus Isolated from the Heavy Metal Contaminated Ennore Creek Sediment, North of Chennai, Tamil Nadu, South East India. Research Journal of Microbiology 2 (2): 133-140.

6. RehmanA, A Zahoor, B Muneer and S Hasnain. 2008. Chromium Tolerance and Reduction Potential of a Bacillus sp.ev3 Isolated from Metal Contaminated Wastewater. Bull Environ Contam Toxicol 81:25-29

7. Rajkumar M, R Nagendran, KJ Lee, WH Lee. 2005. Characterization of a Novel Cr6+ Reducing Pseudomonas sp. with Plant Growth-Promoting Potential. Current Microbiology Vol. 50:266-271

8. Thacker U and D Madamwar 2005. Reduction of toxic chromium and partial localization of chromium reductase activity in bacterial isolate DM1. World Journal of Microbiology \& Biotechnology 21: 891-899. 
9. Banks MK, Schwab AP, \& Henderson C. 2006. Leaching and reduction of chromium in soil as affected by soil organic content and plants. Chemosphere 62:255-264.

10. Putri ARN, 2010. Karakterisasi dan Identifikasi Rhizobakteri yang Meningatkan Serapan Krom pada Tanaman. Skripsi. Program Studi Mikrobiologi Pertanian Fakultas Pertanian UGM. Yogyakarta.

11. Upreti RK, R Shrivastava and UC Chaturvedi. 2004. Gut microflora \& toxic metals: Chromium as a model. Indian J Med Res 119, February, pp 49-59.

12. Cervantes C, Campos-Garc J, Devars S, Gutierrez-Corona F, Loza-Tavera H, Torres-Guzman JC, and MorenoSanchez R, 2001. Interactions of chromium with microorganisms and plants. FEMS Microbiol. Rev. 25: 335-347.

13. De Flora S, BAgnasco M, Serra D, and Zanacchi P. 1990. Denotoxicity of chromium compounds: A review. Muta Res 238:99-172

14. Bae WC, TG Kang, IK Kang, YJ Won, and BC Jeong. 2000. Reduction of Hexavalent Chromium by Escherichia coli ATCC 33456 in Batch and Continuous Cultures. The Journal of Microbiology. Vol. 38 No. 1, p.36-39

15. Bopp LH and HL Ehrlich. 1988. Chromate resistance and reduction in Pseudomonas fluorescens strain LB300. Arch. Microbiol., 150: 426.
16. Alexander, M. 1991. Introduction to Soil Microbiology. John Wiley and Sons. New York.

17. Atlas RM and Bartha R. 1993. Microbial ecology: Fundamental and application. California. Benjamin Cummings Publishing Company.

18. Gadd GM and White C. 1993. Microbial treatment of metal pollution: a working biotechnology 11: 353-392.

19. Priester JH, SG Olson, SM Webb, MP Neu, LE Hersman, and PA Holden. 2006. Enhanced Exopolymer Production and Chromium Stabilization in Pseudomonas putida Unsaturated Biofilms. Applied and Environmental Microbiology, 72:1988-1996

20. Wang YT and H Shen. 1995. Bacterial reduction of hexavalent chromium. J. Ind. Microbiol. 14, 159-164.

21. Ohtake H, E Fujii, and K Toda. 1990. A survey of effective electron donors for reduction of toxic hexavalent chromium by Enterobacter cloacae (strain HO1). J. Gen. Appl. Microbiol. 36, 203-208.

22. Ramirez-Diaz MI, C Diaz-Perez, E Vargas, H Riveros-Rosas, J CamposGarcia, C Cervantes. 2008. Mechanisms of bacterial resistance to chromium compounds. Biometals 21:321-332

23. Kieft TL, Fredrickson JK, Onstott TC, Gorby YA, Kostandarithes HM, Bailey TJ, Kennedy DW, Li SW, Plymale AE, Spadoni CM and Gray MS. 1999. Dissimilatory reduction of $\mathrm{Fe}(\mathrm{III})$ and other electron acceptors by a Thermus 
isolate. Applied and Environmental Microbiology 65:1214-1221.

24. Shanker, A. K., C. Cervantes, H. LozaTavera, dan S. Avudainayagam. 2005. Chromium toxicity in plants. Environ. Int. 31: 739-753.

25. Hara T and Sonoda Y. 1979 Comparison of the toxicity of heavy metals to cabbage growth. Plant Soil 51, $127-$ 133.

26. Hoflich G and Metz R. 1997. Interaction of plant microorganismassociation in heavy metal containing soils from sewage farms. Bodenkultur 48:238247

27. Kramer U, Pickering IJ, Prince RC, Raskin I, and Salt DE. 2000. Subcellular localization and speciation of nickel in hyperaccumulator and non-accumulator Thlaspi species. Plant Physiol 122:1343-1353.

28. Tolra RP, Poschenrieder C, and Barcelo M. 1996. Zinc hyperaccumulation in Thlaspi caerulescens, II. Influence on organic acids. J Plant Nutr 19:15411550
29. Ma JF, Zheng SJ, and Matsumoto H. 1997. Defoxifying aluminum with buckwheat. Nature 390:569-570.

30. Davies Jr., F. T., J. D. Puryear, R. J. Newton, J. N. Egilla, dan J. A. S. Grossi. 2001. Mycorrhizal fungi enhance accumulation and tolerance of chromium in sunflower (Helianthus annuus). J. Plant. Physiol. 158: 777786.

31. Srivastava, S., S. Prakash, dan M. M. Srivastava. 1999. Chromium mobilization and plant availability the impact of organic complexing ligands. Plant Soil 212: 203-208.

32. Yoon, J., X. Cao, Q. Zhou, dan L. Q. Ma. 2006. Accumulation of $\mathrm{Pb}, \mathrm{Cu}$, dan $\mathrm{Zn}$ in native plants growing on a contaminated Florida site. Sci. Total. Environ. 368:456-464.

33. Cervantes C, and Campos-Garcia J. 2007. Reduction and efflux of chromate by bacteria. Mol Microb Heavy Metals Springer-Verlag, Berlin. 